DOI $10.31489 / 2020 \mathrm{Ec} 4 / 5-14$

JEL: J380

UDC: 331.2

\author{
A.K. Amirova \\ Academy of Public Administration under the President of the Republic of Kazakhstan \\ aigerimamirova@gmail.com;a.amirova@apa.kz \\ https://orcid.org/0000-0003-1250-0777
}

\title{
On the issue of transformational management at the Agency for Civil Service Affairs in the course of a new remuneration system piloting
}

\begin{abstract}
Object: is to analyze transformation processes and organizational aspects of the Agency for Civil Service Affairs (hereinafter - the Agency) to determine the guidelines for further improvement of its activities.

Methods: a method of organizational diagnosis, which involves analysis of Strategic plan and organizational structure of the Agency in a prism of foreign experience, description of life cycle, survey of employees as well as the cost-effectiveness analysis of the pilot project in the Agency.

Findings: it was found that (i) despite the direct relationship between bonus payments (or rather the size of the bonus fund) and performance indicators, there is a deterioration in individual indicators. At the same time, the bonus fund has not been adjusted; (ii) the Agency's mission and vision need to be refined in terms of concretization and compliance with the guidelines of the country's strategic documents; (iii) there is a lack of competence, which requires a single state body that will comprehensively address pressing issues of the public administration system; (iv) improvement of business processes in the Agency by taking into account the proposals of respondents.

Conclusions: taking into account the comprehensive diagnostics, the author developed proposals that are aimed not only at improving the Agency's performance, but also at launching systemic changes in the public sector.
\end{abstract}

Keywords: remuneration, pilot project, transformation, innovative civil service, Good Governance, organizational diagnostics, Agency for Civil Service Affairs.

\section{Introduction}

Nowadays we live in a circumstance where not only technologies, but also communication methods are changing rapidly. Citizens' demands not just for timely, but immediate response of the state apparatus to external and internal challenges are increasing. Therefore, any delay from authorities is perceived by the population very acutely. Earlier a law enforcement system and a work of the front offices of state bodies were mainly criticized. But today, taking into account the periodically introduced quarantine regime, the transition to distance learning and work, and the deterioration of the health of citizens, criticism of social services (education, labor, health) has increased. In this regard, the importance of transformation of public authorities in the prism of VUCA world (Volatility, Uncertainty, Complexity, Ambiguity) increases. This should be based on the belief that "there are better ways to serve the interests of the country's citizens than the current and generally accepted ones" (Abouchakra, Khoury, 2015, 25-26).

The critical role of Agile Governance is growing. "The complex, transformative and distributed nature of the Fourth Industrial Revolution demands a new type of governance to address the interlinked dynamics of a pace and synergistic nature of emerging technologies" (World Economic Forum, 2018, 4).

An integral principle of Good Governance is also government openness, which is based on "innovative and sustainable public policies and practices and principles of transparency, accountability and participation that promote democracy and inclusive growth" (OECD, 2016, 34).

According to the World Bank, a quality of public administration in Kazakhstan has improved over the past ten years. However, despite better indicators than in neighboring countries, Kazakhstan lags behind the OECD countries in terms of government performance, reflecting a quality of public services, civil service and its degree of independence from political pressure, a Rule of Law, a quality of legislation and other parameters (World Bank). 
At the same time, if we consider two key strategic documents since independence (Strategy 2030 and Strategy 2050), we can clearly see the criticism of the country's leadership of the measures taken to build a "Professional state".

Thus, comparison between the "Priorities" section of the Strategy 2030 and "Achievements" section of the Strategy 2050 demonstrates that the first six areas show significant improvement and confidence in results obtained.

For example, on National security - "We managed to do more than planned", on Infrastructure - "And we were able to do it", on Economic growth - "We managed to solve this task in the shortest time possible by historical standards", etc.

According to the seventh priority - "Professional state" full conviction is not observed. This is evidenced not only by the quote "We should have...", but also by a lack of clarity and completeness of this task in the Strategy 2050.

This conclusion is reinforced by the statement at the end about individual tasks that are being implemented: "Thus, the main tasks set by the Strategy 2030 have been completed, while others are in a process of implementation". In particular, it was planned to complete a reform of the Government and civil service by 2000 , as well as to clear incompetent officials who abuse power.

In fact, the civil service reform, in particular, and public administration reform, in general, are continuous and take place permanently in a rapidly changing social and economic environment. Similarly, corruption remains one of the unresolved issues today. At the same time, it is noteworthy that the policy guidelines in this area have changed. In particular, preventive measures and anti-corruption education are becoming increasingly important in place of the fight against corruption.

In this regard, to continue the Strategy 2050 reforms five institutional reforms have been identified, which are aimed at strengthening the state and making the country one of the 30 most developed countries in the world by 2050. In addition, a new Concept for the development of public administration for 2020-2025 is being developed, the main postulates of which are the transformation of the functional approach to managing state tasks; ensuring prompt and effective interaction with citizens.

One of the measures of the reform package is a transition to remuneration of civil servants based on results (grading and bonus system). The pilot project was launched in 2018, and the issue of scaling will be considered if structure, number and expenses of state bodies and subordinate organizations will be optimized. The pilot authorities are the Agency for Civil Service Affairs, the Ministry of Justice and several akimats.

At the same time, as repeatedly noted by the country's leadership and Head of the Agency, this project involves not only increasing the salaries of civil servants, but also launching transformational processes.

This research is part of the dissertation and provides a comprehensive assessment of pilot authority (Agency) through the prism of its diagnostics based on innovativeness and principles of Good Governance in the framework of the country's strategic development priorities until 2050. To do this, the key tasks are defined as follows:

- consideration of theoretical aspects of transformational management;

- specification of the research methodology;

- diagnostics of the Agency for Civil Service Affairs;

- development of proposals to improve the efficiency of the state body.

The research hypothesis suggests that despite significant achievements in the field of civil service, the diagnostics of the Agency for Civil Service Affairs will identify reserves for further development of public sector thru the lenses of the country's strategic goals.

\section{Literature Review}

The historiography of transformational management and organizational diagnostics issues is inextricably linked with the permanent development of management theory. A significant contribution to the general management theory in the prism of human resources and organization development was made by R. Owen, C. Babbage, and H. Fayol (the latter author identified five key functions of management).

R. Kalman, S. Simon, J. Forrester have defined the emphasis on the formation of a flexible management structure (project approach) in their research.

In the current reality creative industries of the economy based on knowledge and innovation have developed. Therefore, there is a need for organizational models with a decentralized management structure and focused on employee performance (corporate governance, human resource management). 
Accordingly, new approaches to the management of the organization have appeared, the most prominent representatives are I. Adizes, J. Kotter, whose works study not only various aspects of management, but also various types of leadership, the main criteria for the success of changes, employee engagement, company development life cycles, and more.

Today, there are at least 50 different models of transformational management that are used for private companies. There is no universal model, as well as there is no special model for civil service.

All Change Management Models can be divided into four groups:

1) contextual - broader strategic or macro models that can be helpful in understand a context of change, or support for change - Nadler and Tushman, congruence model being an example;

2) high level - change specific models, but at a broader, sometimes even conceptual model - Carnall, change management model as an example;

3) actionable - detailed, with defined stages and actions, for example Accelerating Implementation Methodology (AIM) Change Management Methodology;

4) supporting - models that underpin our approach to change, they can apply to specific elements of change or help to understand certain elements, for example - Beckhard and Harris, change formula (Simpson, 2017).

Some models based on individual aspects, such as decision-making process, human capital or IT. Therefore, previous management methods no longer effective and require a comprehensive approach (Hamel, 2008; Mintzberg, 2009; Birkinshaw, 2012; Abouchakra, 2015; Adizes, 2016). What is important today is a comprehensive approach with a set of key factors, which often include Leadership, Strategy, Organization, Human Capital, and Budget.

These factors are more or less present in four models of corporate management, each of which has its own key element of the transformational management concept. Namely:

1) southern (humanistic) implies a transition from competitive strategy to strategic renewal through transformational flows;

2) eastern (holistic) - transformation of organizational development into cultural dynamics through transcultural, including cross-cultural efforts;

3) northern (rationalistic) - intensive development of research and development (R\&D) through transdisciplinary areas;

4) western (pragmatic) - improvement of the company's management functions, introduction of transpersonal functions (Lessem, 2009; Suleymankadieva, 2016).

At the same time, transformational management often acts as an integrated science of various individual disciplines, such as strategic management, project management, risk management, management of organizational changes in the company, competence management, etc.

However, the study of the literature has shown that often only certain approaches are used to analyze the current state of the organization. There are no comprehensive diagnostic methods that would also demonstrate the groundwork for the future.

Taking into account the above, in this article, the author attempts to systematically analyze various aspects of the organization's development in terms of the effectiveness of the resources spent and the effects obtained, as well as development guidelines taking into account advanced foreign experience.

\section{Methods}

The key research method is the method of organizational diagnostics. It is defined as the collection of information about an organization in order to identify problems in its functioning, as well as ways and reserves to solve them (Lipatov, 1994).

This method includes a set of different methods based on qualitative and quantitative data. In particular, the analysis is expected to be carried out thru:

1) structural harmony of the state body;

2) comparative analysis with similar foreign authorized bodies;

3 ) the organization's life cycle according to the theory of I. Adizes (Adizes, 2017);

4) a sociological survey of employees;

5) cost effectiveness analysis of the pilot project at the Agency.

The basis for the analysis is the conceptual model of the dissertation research, which consists of five key transformation factors (Leadership, Strategy, Organization, Human Capital, Budget) and a mediation component - Citizen Centricity. 
In this regard, for each type of analysis, these factors are represented by corresponding indicators. For example, to study the life cycle of an organization, the "Leadership" factor will be taken into account, to analyze the structural harmony of the organization, the "Strategy" factor is revealed through the analysis of the Agency's mission, vision and goals, and the "Organization" factor - through the structure of the state body.

At the same time, to study the cost effectiveness of pilot project at the Agency, each of the above mentioned factors is compared to blocks of evaluation system of JSC "Institute of Economic Research" (Goals achievement, Interaction with citizens and Organizational development) and indicators of Agency's statistics ("Net turnover" and "Quality of public services").

Thus, the applied integrated approach allows a comprehensively assess the authorized body in the field of civil service. As we know, for system changes you need to start from yourself.

\section{Results}

Agency diagnostics includes several consecutive stages.

1. First of all, this is an analysis of the strategic guidelines for a development of an organization, a meaning of its existence. Thus, according to the Agency's Strategic plan for 2017-2021, the mission is to implement a unified state policy in the areas of civil service and control of public services' quality.

In turn, the vision is a professional state apparatus that ensures a quality implementation of economic programs and a provision of public services.

In fact, the mission is replaced by a competence of the state body and requires improvement in terms of the philosophy of its creation and functioning. An alternative is to focus on a professional, competent and transparent state apparatus that serve the people of Kazakhstan.

The vision should acquire clear horizons and be inextricably linked to the overall development strategy of the country. For example, it can be "A professional state apparatus that ensures $100 \%$ achievement of the goals of economic programs, including at least $5.2 \%$ of the country's GDP growth, as well as a high level of satisfaction of the population and business with the quality of public services".

Turning to the goals and target indicators, it should be noted that they do not fully reflect the possibilities for improving a supervised area, but contain a minimum required set (i.e., they are achievable and not ambitious), which leads to stagnation.

Some goals are not specific and unclear. For example, "Improving an efficiency of a civil service". To what extent a professionalism of the state apparatus reflected in improving an efficiency of the civil service?

The wording of individual goals is "bureaucratic". For example, "Improving the control of public services quality". The Agency and its employees should be focused not on strengthening control, but on creating conditions for preventing violations and promoting digitalization in the provision of public services.

2. Next, we consider the organizational structure through the prism of foreign experience. As stated in the mission, the Agency is entrusted with functions of implementing a unified state policy in the areas of civil service and control the quality of public services. In addition to territorial divisions in all regions, the Agency has as subordinate organizations the Academy of public administration under the President of the country, as well as the National center for civil service personnel management.

For comparison, let's take, for example, similar departments of such advanced countries in the field of civil service as Singapore and South Korea, whose distinctive feature is the citizen-centric smart government.

These organizations are only assigned functions in the field of civil service and do not include issues of anti-corruption policy (as was previously in the Agency for Civil Service Affairs and Anti-Corruption of Kazakhstan).

Beside this, Public Service Division (Singapore) has:

- the competence to transform the public sector (in Kazakhstan, the functions of public administration and administrative reform are concentrated in the Ministry of National Economy);

- the functions of leadership development;

- a separate Department for maintaining the HR IT-system.

The Ministry of Personnel Management (South Korea) has:

- a more extensive structure for each aspect of the civil service: staff selection, development, remuneration, employment after retirement, etc. (in Kazakhstan, the function of remuneration is assigned to the Ministry of National Economy);

- separate Bureau of innovations. 
Thus, both the Agency and the Ministry of National Economy have separate functions for public administration. Therefore, there is a question of creating a unified authorized body accountable to the President of the country, with a temporary moratorium on its reorganization or abolition. Since only over the past five years, the Agency's structural changes have taken place almost annually.

3. Let's consider the political agenda and the "portrait" of the first leader during this period (2015-2020) based on the life cycle of I. Adizes:

- the Agency for Civil Service Affairs was transformed into the Agency for Civil Service Affairs and Anti-Corruption, ACSAAC (Chairman - K. Kozhamzharov) in 2014. This period can be associated with several phases of the life cycle: active performance, youth, prosperity and stability. This is due to a full-scale change in the legal framework for the development of the civil service system. By the end of 2015, all the necessary legislative acts were adopted as part of the first institutional reform of "100 concrete steps" National Plan, which allowed us to move to the stage of stability, i.e. the systematic implementation of new legislation;

- in December 2015 the ACSAAC was abolished by creating the Ministry for Civil Service Affairs (Minister - T. Donakov), which no longer included anti-corruption functions, transferred to the newly formed Bureau following the example of Hong Kong and Singapore. Despite certain "quick wins", the Ministry continued the policy previously implemented by the Agency. At the same time, the structure has become more branched, the staff of the Central office has been increased, including by strengthening the back office. Excessive "bloated" Organizational and control Division of the Administrative Department and other above-mentioned aspects led to the transition to the aristocracy stage;

- with the appointment A. Shpekbaev as a Chairman of the newly established ACSAAC previously implemented policy was continued. A distinctive feature is the initiation of a number of projects and approaches that, although not systemically, have had a positive impact on the civil service, anti-corruption and public services delivery. At the same time, with the launch of a new payment system in pilot mode, the back office transformation has begun. One of the first initiatives was to reduce the number of personnel service employees of the Agency's territorial divisions by 14 times using the example of shared service centers;

- today we are seeing a return to the original set of functions of the Agency under the leadership of new Chairman, who in the new reality of the pandemic and drastic action is needed to transform the government's work on the principles of efficiency, transparency, customer centricity, innovativeness, allowing to give a new stage of development of the organization.

4. The need for changes is also evidenced by the results of a survey of the Agency's employees $(70 \%$ of the Central apparatus, 2019, April) with an average of 10-15 years of civil service experience. Respondents point to the need for:

- clearly define the strategy and mission;

- changes to the Agency's organizational structure;

- transformational leader;

- digitalization and optimization of business processes for efficient workflow;

- rational distribution of work load;

- delegation of authority ( $79 \%$ of decisions are made at the political level).

These suggestions form a basis of recommendations that are given in the final sections of this article.

5. For a full study of the Agency's work, a cost effectiveness analysis was conducted through the prism of key factors of the author's conceptual model and indicators of the evaluation system of public authorities (Table).

Table. Indicators of Agency's activity for 2017-2019

\begin{tabular}{|c|c|c|c|c|c|}
\hline Factor & Indicators & Year & $\begin{array}{l}\text { Agency for Civil } \\
\text { Service Affairs }\end{array}$ & $\begin{array}{c}\text { Central authorities' } \\
\text { average }\end{array}$ & $\begin{array}{l}\text { Country's } \\
\text { average }\end{array}$ \\
\hline 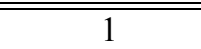 & 2 & 3 & 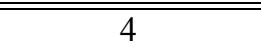 & 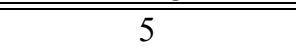 & 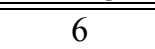 \\
\hline \multicolumn{6}{|c|}{ Effects } \\
\hline \multirow{2}{*}{ Leadership } & \multirow{2}{*}{$\begin{array}{l}\text { Evaluation of overall effective- } \\
\text { ness of a state body }\end{array}$} & 2017 & $89.8 \%$ & $74.8 \%$ & $69.4 \%$ \\
\hline & & 2018 & $91.2 \%$ & $75.5 \%$ & $72.3 \%$ \\
\hline \multirow[t]{2}{*}{ Strategy } & \multirow[t]{2}{*}{ Goal achievement } & 2017 & $97.4 \%$ & $79.3 \%$ & $74.4 \%$ \\
\hline & & 2018 & $93.5 \%$ & $86.3 \%$ & $82.1 \%$ \\
\hline \multirow[t]{2}{*}{ Organization } & \multirow[t]{2}{*}{ Organizational development } & 2017 & $78.5 \%$ & $69.3 \%$ & $68.8 \%$ \\
\hline & & 2018 & $88.5 \%$ & $71.3 \%$ & $69.8 \%$ \\
\hline Human & Net turnover & 2017 & $5.7 \%$ & $6.7 \%$ & $6.2 \%$ \\
\hline
\end{tabular}




\begin{tabular}{|c|c|c|c|c|c|}
\hline 1 & 2 & 3 & 4 & 5 & 6 \\
\hline \multirow[t]{2}{*}{ Capital } & & 2018 & $4.1 \%$ & $7.0 \%$ & $6.2 \%$ \\
\hline & & 2019 & $4.8 \%$ & $6.9 \%$ & $6.0 \%$ \\
\hline \multicolumn{6}{|c|}{ Mediating effect } \\
\hline \multirow{5}{*}{$\begin{array}{l}\text { Citizen } \\
\text { Centricity }\end{array}$} & \multirow{3}{*}{$\begin{array}{l}\text { Quality of public services deliv- } \\
\text { ery }\end{array}$} & 2017 & $79.6 \%$ & $65.9 \%$ & $65.9 \%$ \\
\hline & & 2018 & $86.6 \%$ & $69.8 \%$ & $72.4 \%$ \\
\hline & & 2019 & $80.6 \%$ & $77.1 \%$ & $74.8 \%$ \\
\hline & \multirow[t]{2}{*}{ Interaction with citizens } & 2017 & $84.7 \%$ & $72.5 \%$ & $71.0 \%$ \\
\hline & & 2018 & $91.6 \%$ & $71.3 \%$ & $66.4 \%$ \\
\hline \multicolumn{6}{|c|}{ Costs } \\
\hline \multirow[t]{3}{*}{ Resources } & \multirow[t]{3}{*}{ Budget of Payroll Fund } & 2017 & $6.6 \mathrm{mln} . \mathrm{USD}$ & - & - \\
\hline & & 2018 & $10.5 \mathrm{mln} . \mathrm{USD}$ & - & - \\
\hline & & 2019 & $11.5 \mathrm{mln} . \mathrm{USD}$ & - & - \\
\hline
\end{tabular}

In accordance with the Table above, almost all indicators are higher than the national average and show positive dynamics. Over the past year (the year of pilot project implementation) there has been a downward trend in preventing high net turnover of personnel and the quality of public services by $0.7 \%$ and $6 \%$, respectively.

At the same time, the Agency's payroll expenses increased by 1 million USD due to the bonus payment period. Bonuses are an incentive supplement for effective performance. Thus, there is a question about the size of the bonus fund, taking into account that not all aspects of the Agency's work have shown growth.

\section{Discussion}

In general, there are positive changes in the Agency's work. This is evidenced by individual performance indicators, as well as ongoing image-based initiatives (for example, the "Best civil servant" competition) and on behalf of the country's leadership (transferring the work of civil servants to a remote system, crowdsourcing proposals for reengineering of public service delivery).

However, there are no systematic measures to restructure a work of the state apparatus in response to requests of population during the pandemic (rapid response, transparency and access to departmental data, inefficiency of quasi-public sector organizations). Moreover, there is no up-to-date information on implementation of the first institutional reform in general, and the pilot project, in particular.

Thus, returning to the earlier thought, it is proposed to define a single state body responsible for the functioning of the public sector. This can be either the Agency or a body based on the Department of the Presidential Administration, with the transfer of relevant functions and powers in the field of public administration.

In the first case, the Agency's powers need to be expanded, including an inclusion of functions on remuneration, administrative reform, i.e. the transfer of competencies for the development of the public administration system from the Ministry of National Economy. At the same time, it is possible to create divisions for innovative development and transformation of the public sector in the Agency (in fact, today the Agency initiates and coordinates such work on digitalization of public services, introduction of a new system of remuneration, project management, etc.).

In the case of the second option, in addition to transferring the appropriate staff and authority from the Ministry of National Economy, the feasibility of the Agency's functioning should be considered in order to avoid duplication of functions. The proposals will improve the Agency's performance as the main promoter of reforms in the public sector of the economy.

In addition to the system-wide conclusion, it is necessary to note a number of recommendations in relation to the analyzed state body itself.

As we can see from the organizational diagnostics, every aspect needs to be improved. An integrated approach involves starting changes with a clear definition of the mission, strategy, goals and objectives of this body in the light of the country's strategic documents, including the unachieved results of the Strategy 2030 and Strategy 2050. Beside this, the current management of the Agency may be advised not to be afraid of radical transformations of the public sector, taking into account the expectations of the population and business.

Furthermore, it is proposed to reflect on the overall effectiveness of the budget resources spent on the introduction of a new remuneration system, taking into account the results achieved by each pilot project. Since, as follows from open sources such an analysis was not carried out. Therefore, an example of organiza- 
tional diagnostics and, in particular, a method of cost-effectiveness analysis, will allow to "honestly" responding to the question about feasibility of a pilot project and necessary adjustments.

\section{Conclusions}

As stated at the beginning of the article, in rapidly changing conditions, population expects a prompt response from the state apparatus. Therefore, work restructure of should be carried out everywhere, including central and local authorities, as well as the quasi-public sector.

This type of analysis (organizational diagnostics) allows developing clear recommendations for improving the organization's performance. This will serve as an additional incentive for systemic changes.

The package of recommendations for direct improvement of business processes in the Agency (taking into account the opinion of respondents) provides:

- decentralization of powers from the level of the Chairman and his deputies, increasing the responsibility of units heads (Department Directors, Heads of independent divisions);

- cancellation of the collection of signatures from many co-executors in the absence of their direct competence on the issue;

- optimization of the number of hardware and other meetings, which are often in the nature of hearing reports on work and performance discipline (this is also reported in writing);

- formation of a common database on statistical accounting using Big Data technology and cloud solutions;

- transition to full paperless document management (implementation of the Paper-Free principle);

- cloud-based document management solutions for efficient remote work, etc.

Taking into account the all recommendations we can conclude that the research hypothesis was confirmed. In this regard, as a practical component the proposals will be recommended to the authorized body and Korn Ferry Hay Group company (project manager). Diagnostics is also planned for the remaining pilot authorities.

\section{References}

Abouchakra, R., \& Khoury, M. (2015). Jeffektivnoe pravitel'stvo dlja novogo veka [Effective government for the new century]. Moscow: Olymp-Business Publishing [in Russian]..

World Economic Forum (2018). White Paper. Agile Governance Reimagining Policy-Making in the Fourth Industrial Revolution. Retrieved from https://www.weforum.org.

Organization for Economic Cooperation and Development (2016). Open Government: The Global Context and the Way Forward. Paris: OECD Publishing. DOI: http://dx.doi.org/10.1787/9789264268104-en.

World Bank database. Indicators of the quality of public administration in the countries of the world. Retrieved from http://info.worldbank.org/governance/wgi/index.aspx\#home.

Address of the President of the Republic of Kazakhstan to the People of Kazakhstan (1997). Prosperity, security and ever growing welfare of all the Kazakhstanis. Retrieved from https://www.akorda.kz/en/addresses/addresses_of_president/address-of-the-president-of-the-republic-ofkazakhstan-nursultan-nazarbayev-to-the-people-of-kazakhstan-october-10-1997.

Address of the President of the Republic of Kazakhstan to the People of Kazakhstan (2012). Strategy Kazakhstan-2050: new political course of the established state. Retrieved from https://www.akorda.kz/en/events/astana_kazakhstan/participation_in_events/address-by-the-president-of-therepublic-of-kazakhstan-leader-of-the-nation-nnazarbayev-strategy-kazakhstan-2050-new-political-course-of-theestablished-state-1.

Draft Decree of the President of the Republic of Kazakhstan (2020). O merah po dalnejshej optimizacii sistemy gosudarstvennyh organov Respubliki Kazahstan [On measures to further optimize the system of state bodies of the Republic of Kazakhstan]. Retrieved January 20, 2020 from https://legalacts.egov.kz/npa/view?id=2879622 (the public discussion period is from January 13 to 27,2020 ) [in Russian]..

Simpson, C. (2017). Presentation of the Armour company. Taxonomy of change models. Retrieved from https://www.slideshare.net/MarkSimpson13/taxonomy-of-change-models-slideshare-201703.

Hamel, G. (2008). The Future of Management. Harvard Business Press. Retrieved from https://hbsp.harvard.edu/product/2505-PDF-ENG?itemFindingMethod=Other.

Mintzberg, H. (2009). Managing. Berrett-Koehler Publishers.

Birkinshaw, J. (2012). Reinventing Management. Oxford Leadership Publishing. Retrieved from https://www.oxfordleadership.com/wp-content/uploads/2016/08/oxford-leadership-article-reinventingmanagement.pdf.

Adizes, I. (2016). Mastering Change: Introduction to Organizational Therapy. Adizes Institute Publications.

Lessem, R., Schieffer, A. (2009). Transformation Management. Towards the Integral Enterprise. USA, England. 
Suleymankadieva, A. (2016). Teorija i metodologija transformacionnogo menedzhmenta [Theory and methodology of transformational management]. Saint Petersburg: SPbGJeTU "LJeTI” Publishing [in Russian]..

Lipatov, S. (1994). Metody social'no-psihologicheskoj diagnostiki organizacij [Methods of socio-psychological diagnostics of organizations]. In J. Zhukov, L. Petrovskij, O. Solov'eva (Ed.). Vvedenie v prakticheskuju social'nuju psihologiju [Introduction to practical social psychology] [in Russian]..

Adizes, I. (2017). Managing Corporate Lifecycles. Adizes Institute Publications.

Strategicheskij plan Agentstva Respubliki Kazahstan po delam gosudarstvennoj sluzhby na 2017-2021 gody [Strategic plan of the Agency of the Republic of Kazakhstan for Civil Service Affairs for 2017-2021]. Retrieved from https://www.gov.kz/memleket/entities/qyzmet/documents/details/1085?lang=ru [in Russian].

Rezultaty obshchestvennogo monitoringa kachestva okazaniya gosudarstvennyh uslug za 2017 god [Report on Public monitoring of the quality of public services delivery in 2017]. Retrieved from http:/qogam.gov.kz/ru/pages/rezultaty-obshchestvennogo-monitoringa-kachestva-okazaniya-gosudarstvennyhuslug-za-2017-god [in Russian]..

Rezultaty obshchestvennogo monitoringa kachestva okazaniya gosudarstvennyh uslug za 2018 god [Report on Public monitoring of the quality of public services delivery in 2018]. Retrieved from http://www.qogam.gov.kz/ru/pages/obshchestvennyy-monitoring-kachestva-okazaniya-gosudarstvennyh-uslug2018 [in Russian]..

Rezultaty obshchestvennogo monitoringa kachestva okazaniya gosudarstvennyh uslug za 2019 god [Report on Public monitoring of the quality of public services delivery in 2019]. Retrieved from https://data.egov.kz/datasets/view?index=memlekettik_kyzmetter_korsetu_ 1 [in Russian]..

Rezultaty ocenki jeffektivnosti gosudarstvennyh organov za $2016-201 \overline{8}$ gody [Results of evaluation of government authorities' effectiveness in 2016-2018]. Retrieved from https://www.bagalau.kz/results/govagency/2 [in Russian]..

\section{А.К. Әмірова}

\section{Мемлекеттік қызмет істері агенттігінде еңбекақы төлеудің жаңа жүйесінің пилоттық жоба барысындағы трансформациялық менеджмент мәселесіне қатысты}

Maқcambl: Мемлекеттік қызмет істері агенттігінің (бұдан әрі - Агенттік) қызметін одан әрі жетілдіру бағдарларын айқындау үшін оның трансформациялық процестерін және ұйымдастырушылық аспектілерін талдау болып табылады.

Әдістер: Ұйымдастырушылық диагностика әдісі, оның құрамына шетелдік тәжірибе призмасында Агенттіктің стратегиялық жоспары мен ұйымдық құрылымының параметрлерін талдау, өмірлік циклдің сипаттамасы, қызметкерлерге әлеуметтік сауалнама жүргізу, сондай-ақ Агенттіктегі пилоттық жоба шығындарының тиімділігін бағалау кіреді.

Нәтижелері: (i) бонустар (дәлірек айтқанда бонустық қор мөлшері) мен жұмыс көрсеткіштерінің тікелей өзара байланысына қарамастан, жекелеген индикаторлардың нашарлауы байқалатыны анықталды. Бұл ретте бонустық қор түзетілмеген; (ii) елдің стратегиялық құжаттарын нақтылау және бағдарларға сәйкестігі бөлігінде агенттіктің миссиясы мен пайымын пысықтау талап етіледі; (iii) құзыреттілік бұлдырлығы бар, осыған байланысты мемлекеттік басқару жүйесінің өзекті мәселелерін кешенді шешетін бірыңғай мемлекеттік орган қажет; (iv) респонденттердің ұсыныстарын ескере отырып, Агенттікте бизнес-процестерді жетілдіру талап етіледі.

Kорытынды: Жүргізілген кешенді диагностиканы ескере отырып, автор Агенттіктің жұмысын жетілдіруге ғана емес, сонымен бірге мемлекеттік сектордағы жүйелік өзгерістерді іске қосуға бағытталған ұсыныстар жасаған.

Kiлm сөздер: еңбекақы төлеу, пилоттық жоба, трансформация, инновациялық мемлекеттік қызмет, тиімді басқару, ұйымдастырушылық диагностика, Мемлекеттік қызмет істері агенттігі.

\section{А.К. Амирова}

\section{К вопросу трансформационного менеджмента в Агентстве по делам государственной службы в ходе пилотирования новой системы оплаты труда}

\section{Аннотация}

Цель: Целью является анализ трансформационных процессов и организационных аспектов Агентства по делам государственной службы (далее - Агентство) для определения ориентиров дальнейшего совершенствования деятельности.

Memodbl: Метод организационной диагностики, который включает в себя анализ параметров стратегического плана и организационной структуры Агентства в призме зарубежного опыта, описание жизненного цикла, проведение социологического опроса сотрудников, а также оценку эффективности затрат пилотного проекта в Агентстве.

Pезультаты: Установлено, что (i), несмотря на прямую взаимосвязь выплаты бонусов (а точнее, размера бонусного фонда) и показателей работы, отмечается ухудшение отдельных индикаторов. При этом бонусный 
фонд не корректировался; (ii) требуется доработка миссии и видения Агентства в части конкретизации и соответствия ориентирам стратегических документов страны; (iii) существует размытость компетенции, в связи с чем необходим единый государственный орган, который комплексно будет решать насущные вопросы системы государственного управления; (iv) требуется совершенствование бизнес-процессов в Агентстве с учетом предложений респондентов.

Bblвoдbl: На основе проведенной комплексной диагностики автором выработаны предложения, которые направлены не только на совершенствование работы Агентства, но и запуск системных преобразований в государственном секторе.

Ключевые слова: оплата труда, пилотный проект, трансформация, инновационная государственная служба, эффективное управление, организационная диагностика, Агентство по делам государственной службы.

\section{References}

Абучакра Р. Эффективное правительство для нового века / Р. Абучакра, М. Хури. - М.: Олимп-Бизнес, 2015. $-155 \mathrm{c}$.

World Economic Forum. White Paper. Agile Governance Reimagining Policy-Making in the Fourth Industrial Revolution [Текст]. - 2018. - P. 17. - (https://www.weforum.org).

Organization for Economic Cooperation and Development. Open Government: The Global Context and the Way Forward [Текст]. - Paris: OECD Publishing, 2016. — P. 141. — (http://dx.doi.org/10.1787/9789264268104-en).

Всемирный Банк базы данных. Показатели качества государственного управления в странах мира [Текст]. (http://info.worldbank.org/governance/wgi/index.aspx\#home).

Address of the President of the Republic of Kazakhstan to the People of Kazakhstan. Prosperity, security and ever growing welfare of all the Kazakhstanis [Текст]. — 1997. — (https://www.akorda.kz/en/addresses/ addresses_of_president/address-of-the-president-of-the-republic-of-kazakhstan-nursultan-nazarbayev-to-the-people-ofkazakhstan-october-10-1997).

Address of the President of the Republic of Kazakhstan to the People of Kazakhstan. Strategy Kazakhstan-2050: new political course of the established state [Текст]. — 2012. — (https:/www.akorda.kz/en/events/ astana_kazakhstan/participation_in_events/address-by-the-president-of-the-republic-of-kazakhstan-leader-of-thenation-nnazarbayev-strategy-kazakhstan-2050-new-political-course-of-the-established-state-1).

Проект Указа Президента Республики Казахстан «О мерах по дальнейшей оптимизации системы государственных органов Республики Казахстан» (период публичного обсуждения с 13 по 27 января 2020 г.) [Текст]. — (https://legalacts.egov.kz/npa/view? id=2879622).

Simpson C. Presentation of the Armour company. Taxonomy of change models [Текст]. - 2017. (https://www.slideshare.net/MarkSimpson13/taxonomy-of-change-models-slideshare-201703).

Hamel G. The Future of Management. Harvard Business Press [Текст]. _ $2008 . \quad-$ (https://hbsp.harvard.edu/product/2505-PDF-ENG? itemFindingMethod=Other).

Mintzberg H. Managing [Текст]. — Berrett-Koehler Publishers, 2009.

Birkinshaw J. Reinventing Management [Текст]. - Oxford Leadership Publishing, $2012 . \quad-$ (https://www.oxfordleadership.com/wp-content/uploads/2016/08/oxford-leadership-article-reinventingmanagement.pdf).

Adizes I. Mastering Change: Introduction to Organizational Therapy [Текст]. — Adizes Institute Publications, 2016. — P. 298.

Lessem R., Schieffer A. Transformation Management. Towards the Integral Enterprise [Текст]. — USA, England, 2009. - P. 352.

Сулейманкадиева А. Э. Теория и методология трансформационного менеджмента [Текст]. - СПб.: СПбГЭТУ «ЛЭТИ», 2016. - $168 \mathrm{c}$.

Липатов С.А. Методы социально-психологической диагностики организаций [Текст] // Введение в практическую социальную психологию / под ред. Ю.М.Жукова, Л.А.Петровской, О.В.Соловьевой. — М., 1994.

Adizes I. Managing Corporate Lifecycles [Текст]. — Adizes Institute Publications, 2017.

Стратегический план Агентства Республики Казахстан по делам государственной службы на 2017-2021 годы [Текст]. — (https://www.gov.kz/memleket/entities/qyzmet/documents/details/1085? lang=ru).

Министерство информации и общественного развития Республики Казахстан. Результаты общественного мониторинга качества оказания государственных услуг за 2017 год [Текст]. (http://qogam.gov.kz/ru/pages/rezultaty-obshchestvennogo-monitoringa-kachestva-okazaniya-gosudarstvennyhuslug-za-2017-god).

Министерство информации и общественного развития Республики Казахстан. Результаты общественного мониторинга качества оказания государственных услуг за 2018 год [Текст]. (http://www.qogam.gov.kz/ru/pages/obshchestvennyy-monitoring-kachestva-okazaniya-gosudarstvennyh-uslug2018).

Министерство информации и общественного развития Республики Казахстан. Результаты общественного мониторинга качества оказания государственных услуг за 2019 год [Текст]. (https://data.egov.kz/datasets/view? index=memlekettik_kyzmetter_korsetu_1). 
Центр оценки эффективности государственных органов АО «Институт экономических исследований». Результаты оценки эффективности государственных органов за 2016-2018 годы [Текст]. (https://www.bagalau.kz/results/govagency/2). 